\title{
ВПЛИВ РЕАБІЛІТАЦІЙНОЇ ПРОГРАМИ НА ЯКІСТЬ ЖИТТЯ У ПАЦІЕНТВ ІЗ БРОНХІАЛЬНОЮ ОБСТРУКЦІЄЮ РІЗНОГО ГЕНЕЗУ
}

\author{
В. Є. Городецький, Т. М. Кваша \\ ДВНз «Тернопільський державний медичний університет \\ імені I. Я. Горбачевського МОЗ України»
}

у статті проаналізовано вплив реабілітаційної програми на якість життя у пацієнтів із бронхіальною обструкцією та роль медичної сестри у проведенні опитувань пацієнтів даної групи.

\section{THE EFFECT OF THE REHABILITATION PROGRAM ON QUALITY OF LIFE IN PATIENTS WITH BRONCHIAL OBSTRUCTION OF DIFFERENT GENESIS}

\author{
V. Ye. Horodetskyy, T. M. Kvasha \\ I. Horbachevsky Ternopil State Medical University
}

The article analyzes the effect of the rehabilitation program on quality of life in patients with bronchial obstruction and the role of the nurse in conducting polls of this group of patients.

Вступ. Бронхо-обструктивний синдром (БОС) - це патологічний стан, зумовлений порушенням бронхіальної прохідності з подальшим збільшенням опору потоку повітря при вентиляції. БОС є невід'ємним проявом або факультативним ускладненням багатьох захворювань респіраторної системи $[1,8]$. Даний синдром супроводжує і специфічні, і неспецифічні ураження легень, а за останні роки відбулись суттєві зміни в частоті та характері бронхологічних змін, зокрема, і при туберкульозі (ТБ) $[3,5,6]$. Також БОС створює сприятливі умови для тривалої персистенції мікобактерії туберкульозу та недостатньої концентрації антимікобактеріальних препаратіву ділянках активного запалення, тобто здатний негативно впливати на ефективність лікування відповідних категорій хворих $[4,7,8]$. У свою чергу, характерне для хронічного обструктивного запалення легень (ХОЗЛ) хронічне обмеження дихальних шляхів зумовлене поєднанням захворювання дрібних дихальних шляхів (обструктивний бронхіоліт) та деструкції паренхіми (емфізема), відносний вклад кожної складової різний у різних хворих. Хронічне запалення призводить до структурних змін та звуження дрібних повітропровідних шляхів [1, 2].

Варто зазначити, що хронічний перебіг патології, порушення функціональних можливостей та тривала

(c) В. Є. Городецький, Т. М. Кваша, 2016 терапія призводять до зміни способу життя пацієнта, виникає соціальна дизадаптація та погіршення якості життя (ЯЖ).

За останні роки інтерес до вивчення ЯЖ хворих на ХОЗЛ та ТБ в усьому світі значно зріс. Насамперед це пояснюється тим, що дані захворювання супроводжуються дихальним дискомфортом, емоційна значимість якого часом перевищує больовий синдром [9].

Все вищевказане стало основою для проведення даного дослідження, метою якого $є$ вивчення якості життя до та після проведення реабілітаційних програм у хворих із БОС специфічного та неспецифічного генезу.

Основна частина. Під спостереженням перебувало 60 пацієнтів на легеневу бронхіальну обструкцію різного генезу. 30 з них - хворі на ХОЗЛ, інші 30 - на ТБ. У кожній з груп чоловіків було 17 (56,6 \%), жінок 13 (43,4 \%). Вік хворих коливався від 29 до 63 років (середній вік 46ะ1,5 року). Обидві групи пацієнтів були однорідними між собою за статтю, віком та клінічними формами ТБ та ХОЗЛ (Р<0,05 для всіх випадків). Даний діагноз був встановлений на попередніх етапах спостереження хворих із урахуванням результатів спірометричного дослідження. Всім хворим проводили ретельний моніторинг клініко-функціональних ознак захворювання, лабораторно-інструментальне 
обстеження та дослідження якості життя за допомогою селективної «Респіраторної анкети госпіталю Святого Георгія».

Золотим стандартом відбору до дослідження була спірографія та її основні оцінювальні параметри:

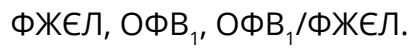

Також було проаналізовано:

- структуру хворих на ХОЗЛ та ТБ за віком, статтю;

- частку виявлення ХОЗЛ і ТБ у хворих зі скаргами на БОС;

- швидкість виникнення стійкого БОС при ХОЗЛ та ТБ;

- причини госпіталізації хворих зі скаргами на БОС;

- наявність шкідливих звичок.

Критерії включення в основну групу: інформована згода пацієнта на участь в дослідженні; вік старше 18 років; БОС при діагнозах ВДТБ органів дихання та ХОЗЛ; показник ОФВ $<80$ \% від належного.

Із дослідження були виключені хворі на ХОЗЛ та ТБ вкрай тяжкого перебігу, в анамнезі яких відмічались наявність бронхіальної астми, тяжкі неконтрольовані супутні захворювання, підвищена чутливість до застосованого пульмонологічного лікування.

Дослідження якості життя проводилось за допомогою селективної «Респіраторної анкети госпіталю Святого Георгія» («St. George's Respiratory Questionnaire» (SGRQ), де в якості оцінювальних параметрів застосовуються 4 узагальнених шкали: «Симптоми»суб'єктивна оцінка пацієнтом ступеня виразності клінічних ознак; «Активність» - суб'єктивна оцінка пацієнтом ступеня обмеження фізичної активності, зумовленої захворюванням; «Вплив» - суб'єктивна оцінка пацієнтом виразності психологічних і соціальних проблем у результаті захворювання і «Сума» загальний показник Яж, що характеризує в цілому негативний вплив захворювання на стан здоров'я.

Оцінка кожної шкали проводиться за 100-бальною системою. Оцінювальні критерії є зворотними: чим вищий бал, тим більш негативним $є$ вплив хвороби на ЯЖ пацієнта. Даний опитувальник дозволяє розраховувати яж хворих як у цілому, так і окремо за кожною із трьох шкал.

У результаті ознайомлення з різними реабілітаційними програмами при даній патології було обрано програму легеневої реабілітації інституту яновського, яка ґрунтується на наказах МОз України: № 555 від 27.06.2013 р. «Про затвердження та впровадження медико-технологічних документів зі стандартизації медичної допомоги при хронічному обструктивному захворюванні легень» та № 601 від 03.08.2012 р. «Про затвердження та впровадження медико-технологічних документів зі стандартизації медичної допомоги при припиненні вживання тютюнових виробів». Ключовими пріоритетами цієї програми є: ретельна діагностика, припинення куріння, ефективне лікування інгаляціями, використання неінвазивної вентиляції, лікування загострень та власне сама пульмонологічна реабілітація, яка включає фізичне тренування, навчання хворих, поради щодо харчування, фізіотерапію та освітню роботу з хворими. Дана реабілітаційна програма складалася із загальної та спеціальної частин. У загальній частині розглядалися питання, які орієнтовані на ведення здорового способу життя (відмову від куріння та алкоголю), організацію умов праці та побуту, первинну та вторинну профілактику захворювань, пропаганду занять фізкультурою та спортом. Спеціальне навчання включало: показ мультимедійного навчального курсу із ХОЗЛ та ТБ, вивчення причин загострення бронхообструкції при даних захворюваннях та методів їх попередження, обговорення необхідності адекватного та регулярного лікування, консультації щодо харчування хворих, консультації із фізичної реабілітації (дихальна гімнастика, дозована ходьба).

Статистична обробка отриманих результатів проводилася за допомогою багатофакторного дисперсійного аналізу (пакет ліцензійних програм «Microsoft Excel», «Statistica 6.0»).

При аналізі показників, що враховувались при анкетуванні за опитувальником SGRQ (табл. 1), виявлено, що наявність ТБ у пацієнтів із БОС вірогідно посилює негативний вплив захворювання на виразність клінічних ознак, ступінь обмеження фізичної активності, поглиблює психологічні та соціальні проблеми пов'язані із захворюванням та погіршує загальний показник ЯЖ. Причому, наявність такої супутньої патології, як ХОЗЛ у пацієнтів з БОС, здійснює менш негативний вплив, ніж ТБ. Та все ж значно впливає на якість життя, що проявляється виразними змінами у суб'єктивному сприйнятті пацієнтом свого фізичного та психосоціального статусу. Дані обставини можуть вносити певні корективи у перебіг захворювання, ефективність лікування та реабілітаційні заходи у хворих із ХОЗЛ та ТБ, що потрібно враховувати при веденні даної категорії хворих.

Аналіз даних моніторингу показника ОФВ 1 у хворих досліджуваних груп встановив, що спірометричні показники при ХОЗЛ склали: ОФВ $-(67,3 \pm 2,76) \%$ та 
таблиця 1. Показники якості життя за опитувальником SGRQ в балах у обстежених хворих

\begin{tabular}{|l|c|c|}
\hline \multicolumn{1}{|c|}{ Показник } & Хворі на ХОЗЛ & Хворі на ТБ \\
\hline Симптоми & $48,58 \pm 2,21$ & $70,52 \pm 1,63$ \\
\hline Активність & $62,95 \pm 1,93$ & $70,64 \pm 1,24$ \\
\hline Вплив & $61,65 \pm 2,17$ & $65,46 \pm 1,72$ \\
\hline Сума & $60,03 \pm 2,46$ & $67,85 \pm 2,18$ \\
\hline
\end{tabular}

ОФВ 1 - $(42,2 \pm 1,38) \%$ при ТБ відповідно. Дослідження показало значне зниження показників у хворих на ТБ порівняно з хворими на ХОЗЛ (р<0,001). Зате після проведення пульмонологічної реабілітації ОФВ 1 при ХОЗЛ становив $(76,71 \pm 3,99) \%$, а при ТБ ОФВ 1 становив $(62,57 \pm 4,17) \%(P<0,01)$. Варто також зазначити, що бронхологічні зміни при туберкульозі мають певну особливість, оскільки запалення розвивається, як правило, перибронхіально, переходячи з легеневої паренхіми на бронхіоли та дрібні бронхи. Зважаючи на це, повного відновлення дренажної функції бронхів у ділянках активного запального процесу за достатньо короткий термін ми не очікували.

Дані селективного опитувальника SGRQ, отримані від респондентів досліджуваних груп після проведення реабілітації (табл. 2), також покращились: компонент «Симптоми» незначно: на $(5,56 \pm 1,75) \%$ при ХОЗЛ та $(6,95 \pm 1,86) \%$ при ТБ відповідно; компонент «Активність» на $(26,05 \pm 1,16) \%$ при ХОЗЛ та $(10,90 \pm 1,26) \%$ при ТБ; та найкращий результат показав компонент «Вплив» на $(58,81 \pm 1,86) \%$ при ХОЗЛ та $(35,59 \pm 1,45) \%$ $(p<0,01)$.

таблиця 2. Показники якості життя за опитувальником SGRQ в балах у обстежених хворих після 6-тижневої реабілітації

\begin{tabular}{|l|c|c|}
\hline \multicolumn{1}{|c|}{ Показник } & Хворі на ХОЗЛ & Хворі на ТБ \\
\hline Симптоми & $45,89 \pm 2,74$ & $65,61 \pm 1,96$ \\
\hline Активність & $46,56 \pm 2,46$ & $62,95 \pm 2,32$ \\
\hline Вплив & $25,84 \pm 2,83$ & $42,16 \pm 2,17$ \\
\hline Сума & $36,07 \pm 2,26$ & $52,35 \pm 2,45$ \\
\hline
\end{tabular}

Висновки. Застосування сучасних методик оцінки якості життя у хворих на хОЗЛ та ТБ дає можливість оцінити рівень благополуччя і задоволення тими сторонами життя, на які впливає хвороба чи лікування. Проведення опитування $\epsilon$ важливою складовою в структурі діяльності медичної сестри з пацієнтами. Застосування сучасних опитувальників $\epsilon$ вагомим практичним та об'єктивним елементом діагностичного пошуку, а також кроком до усвідомлення власної патології пацієнтом. Також доведено, що поєднання сучасної пульмонологічної реабілітації у хворих із БОС при ХОЗЛ та ТБ має суттєві переваги перед вико-

\section{ЛITEPATУРА}

1. Бредер В. В. Якість життя онкологічних хворих [Електронний ресурс] / В. В. Бредер ; Російський онкологічний науковий центр ім. Н. Н. Блохіна РАMН // IV Російська онкологічна конференція : матеріали конференції. Москва. - Режим доступу : http://www.rosoncoweb.ru.

2. Вассерман Л. И. Методология исследования качества жизни в контексте психосоматических и соматопсихических соотношений / Л. И. Вассерман, Е. А. Трифонова // Обозрение психиатрии и медицинской психологии им. В. М. Бехтерева. - 2006. - № 4. - С. 12-15. ристанням лише стандартного режиму специфічного лікування. Тож бачимо, що дані заходи дозволяють прискорити динаміку респіраторних симптомів, покращити показники функції зовнішнього дихання та підвищити якість життя пацієнтів на специфічні та неспецифічні ураження легень. Не менш важливим $\epsilon$ те, що за рахунок навчальних програм для хворих на ХОЗЛ та ТБ у короткі терміни та при незначних матеріальних затратах можливо досягнути покращення якості життя більшості хворих та збільшити їхню прихильність до лікування.

3. Гришин М. Н. Опыт применения тиотропия бромида при бронхообструктивном синдроме у впервые выявленных больных деструктивным туберкулёзом легких / М. Н. Гришин, О. Б. Тимченко // Укр. пульмонол. журн. - 2009. - № 1. - С. 13-16.

4. Зайков С. В. Бронхообструктивный синдром: принципы диагностики и терапии / С. В. Зайков // Укр. пульмонол. журн. - 2009. - № 1. - С. 45-49.

5. Ільницька Л. І. Особливості ендоскопічних проявів запалення слизової оболонки бронхіального дерева при 
туберкульозі органів дихання у підлітків / Л. І. Ільницька // Укр. пульмонол. журн. - 2007. - № 4. - С. 29-32.

6. Мельник В. М. Патоморфоз туберкульозу легень за клінічним перебігом, рентгенологічними та бактеріологічними змінами в умовах епідемії / В. М. Мельник, І. О. Новожилова, В. Г. Матусевич //Укр. пульмонол. журн. 2007. - № 2. - C . 49-53.

7. Норейко С. Б. Лікування туберкульозу легень, ускладненого бронхообструктивним синдромом / С. Б. Норей- ко // Укр. пульмонол. журн. - 2008. - № 3. - С. 171-172.

8. Шмелёв Е. И. Бронхообструктивный синдром и его коррекция у больных туберкулёзом легких/Е. И. Шмелёв // Consilium medicum. - 2007. - № 4. - C. 5-7.

9. Integrating mental health into primary care: a global perspective. Geneva. World Health Organization and World Organization of Family Doctors (WONCA). WHO Press, World Health Organization: 2008. - 210 p.

Отримано 11.10.16 